\title{
Study on the Effects of Phosphorus Levels on Growth and Yield of Chickpea (Cicer aritinum L.)
}

\author{
Mukesh Kumar Pandey ${ }^{1 *}$, Aditya Sirmour ${ }^{1}$ and Varun Pratap Jadaun ${ }^{2}$ \\ ${ }^{1}$ Department of Farm Machinery and Power Engineering, IGKV, Raipur, India \\ ${ }^{2}$ Department of Extension, KVK, GUNA, India \\ *Corresponding author
}

\begin{abstract}
A B S T R A C T
Keywords

Chickpea, Harvest index, Phosphorus levels and yield

Article Info

Accepted: 06 December 2017 Available Online: 10 January 2018

A field experiment was conducted to measure the effect of phosphorus levels $\left[0 \mathrm{~kg}\left(\mathrm{P}_{0}\right), 25 \mathrm{~kg}\left(\mathrm{P}_{1}\right), 40 \mathrm{~kg}\left(\mathrm{P}_{2}\right)\right.$ and $\left.55 \mathrm{~kg}\left(\mathrm{P}_{3}\right) \mathrm{P}_{2} \mathrm{O}_{5} \mathrm{ha}^{-1}\right]$ on chickpea variety JG-14. The height of main shoots $(47.56 \mathrm{~cm})$, fresh weight plant $^{-1}(22.50 \mathrm{~g})$ and dry weight/plant $(13.50 \mathrm{~g})$ were recorded significantly higher in $\mathrm{P}_{3}$. Seed yield for $\mathrm{P}_{3}$ was recorded $17.00 \mathrm{q} \mathrm{ha}^{-1}$ which is significantly higher as compare to $\mathrm{P}_{0}\left(11.45 \mathrm{q} \mathrm{ha}^{-1}\right), \mathrm{P}_{1}\left(11.50 \mathrm{q} \mathrm{ha} \mathrm{q}^{-1}\right)$ and $\mathrm{P}_{2}$ $\left(14.77 \mathrm{q} \mathrm{ha}^{-1}\right)$. The biomass yield $34.36 \mathrm{q} \mathrm{ha}^{-1}$ and straw yield $17.36 \mathrm{q} \mathrm{ha}^{-1}$ were recorded significantly maximum in $\mathrm{P}_{3}$ followed by $\mathrm{P}_{2}, \mathrm{P}_{1}$ and $\mathrm{P}_{0}$ (control) respectively. Harvest index 49.76 was no significantly affected by different levels of phosphorus.
\end{abstract}

\section{Introduction}

Chickpea (Cicer arietinum L), also known as Bengal gram is the most important pulse crop in India and occupies more than one third of the total cultivated area and contributes to half the total production of pulses in the country. It is a drought tolerant leguminous crop used in various foods in several developing countries including India as a source of highly digestible (70-90\%) dietary protein. The pulse production during 2011-12 is 17.21 million tones. The yield of chickpea was found to be less in farmer's field mainly due to the inappropriate production practices and biotic/abiotic stresses. It is reported that resistance to biotic and abiotic stress is negatively related to yield. Pulses require phosphorus for growth and nitrogen fixation. Since it helps for better root development, phosphorus application is a must for the crops grown under rainfed conditions. Recent researches revealed that there is a good response of chickpea to phosphorus fertilizer. If the phosphate availability from the soil is limited, the growth and nitrogen fixation are affected (Prasad and Sanoria, 1981). Influence of phosphorus on root growth and nodule nitrogen fixation which affects the nutrients uptake is well known. Low soil fertility, 
particularly phosphorus (P) deficiency, is one of the major constraints to increasing chickpea productivity. The chickpea breeding program in India has not yet considered the varietal variation in phosphorus (P) efficiency of chickpea varieties. In general, phosphorus application to chickpea is at sub-optimum levels, efficient P-utilizing varieties will perform better than others under P-deficient conditions.

The most common varieties of chickpea used in Central India were selected to study their response to different levels of phosphorus. Since phosphorus is exceptionally important for the pulse crop especially chickpea and the behavior of phosphorus in soil varies with the soil conditions, this study is important for the efficient use of phosphorus, a costly input in agriculture. PGPR strains, CP 11, PSB 11 and $\mathrm{J} 7$, showed consistent response in increasing chickpea grain yield from 14 to $27 \%$ over control in the fields for the last two years, and have been identified for commercial use in chickpea (Anonymous, 2012-13).

\section{Materials and Methods}

A field experiment was conducted during the winter (rabi) season of 2013-14 under the Project "Niche Area of Excellence - Farm Mechanization in Rainfed Agriculture (NAEFMIRA)" at IGKV, Raipur (C.G.). The location of the experimental site was Instructional Farm of Indira Gandhi Agricultural University; Raipur (CG) The soil of the experimental site is characterized by silt clay texture, locally known as "Dorsa". It falls under Alfisols and belongs to mixed Hyperthermic udic Haplastalfs. Mostly Alfisols are bunded and leveled and occur generally, on mid land situation of landscape in Chhattisgarh plains. Initial soil samples were collected using a screw auger to a 15-20 cm depth. Organic carbon and available N, P and $\mathrm{K}$ were analyzed adapting a method outlined by Jackson (1973). pH of 7.12 (1:2.5 soil and water suspension), electrical conductivity $0.52 \mathrm{dSm}^{-1}$ (1:2.5 soil and water suspension) and organic carbon level of $5.60 \%$ and available N, P and K were 241, 19.44 and $330 \mathrm{~kg} \mathrm{ha}^{-1}$, respectively. Land preparation was carried out by tractor ploughing followed by harrowing. Influence on the effect of phosphorus levels treatment $(0,25 \mathrm{~kg}, 40 \mathrm{~kg}$. and $55 \mathrm{~kg} \mathrm{P}_{2} \mathrm{O}_{5} / \mathrm{ha}$ ) in tried four in a factorial randomized block design with three replications.

The soil of the experimental field was silty loam (Dorsa) in texture, medium in organic matter, medium in available phosphorus and potassium with a $\mathrm{pH}$ of 7.8. The chickpea variety JG-14 was shown on $28^{\text {th }}$ November 2013 and harvested on 8 April 2014 respectively. The entire phosphorus was applied through diammonium phosphate at sowing time and equal dose of nitrogen @ 20 $\mathrm{kg} / \mathrm{ha}$ was applied to each treatment as basal application. The sowing of seed was done in line with seed drill at $45 \mathrm{~cm}$ row spacing with a plant to plant distance of $10 \mathrm{~cm}$ and depth 2$3 \mathrm{~cm}$ apart. The plots were kept free from weeds by pre-emergent spray of Pendimethalin 30EC@ $1 \mathrm{~kg}$ a.i. ha ${ }^{-1}$ followed by one hand weeding at 20 days after sowing (DAS).

Five plants were taken randomly from each plot for recording observations. Crop was manually harvested and threshed after sun drying. Harvest index was calculated by dividing the seed yield with that of biological yield (seed + straw). Phosphorus content in the grain was analysed by vanadomolybdophosphoric yellow colour method (Jackson, 1973) and phosphorus uptake by grain was calculated by dividing the product of grain dry weight in $\mathrm{kg} \mathrm{ha}^{-1}$ to protect the crop excessive pod damage by pod borer, one spray of Endosulfan 35EC@0.07\% was given in a year. 


\section{Results and Discussion}

\section{Influence of phosphorus levels on growth, yield attributing}

\section{Growth on yield parameters}

Data presented in table 1 and 2 showed that growth characters viz. initial plant population per running meter, plant height $(\mathrm{cm})$, primary and secondary branches per plant, number of nodules per plant and fresh weight dry weight (g) per plant, were recorded maximum to $\mathrm{P}_{3}$ phosphorus levels followed by $\mathrm{P}_{2}, \mathrm{P}_{1}$ and $\mathrm{P}_{0}$ the initial plant population was found no significant the phosphorus a great role as a nutrient for proper root development and proliferation and multiplication of tissues photosynthesis and maintenance of hybridization which ultimately increases the growth of plant. The similar results were found by Aziz, M.A. (2000), Sawires, E.S. (2001).

Yield attributing branches and yield : data embodied in table 3 and 4 show that growth character wise number of pods per plant, weight of pods/plant (g), Number of seed/plant (g) weight of seed/plant (g), test weight/plant $(\mathrm{g})$, biomass yield $(\mathrm{q} / \mathrm{ha})$, grain yield $(\mathrm{q} / \mathrm{ha})$, straw yield $(\mathrm{q} / \mathrm{ha})$ and harvest index (\%) were maximum with $\mathrm{P}_{3}$ followed by $\mathrm{P}_{2}, \mathrm{P}_{1}$ and $\mathrm{P}_{0}$.

The yield attribute were increase due to growth of plant by using proper amount of phosphorus which helps to farm good photosynthesis and also involved in protein synthesis. The increase in seed yield $(\mathrm{q} / \mathrm{ha})$ is the positive effect of per plant seed weight and yield contributing character. The above all yield attributes were enhanced and pushed for increasing seed yield in $\mathrm{q} / \mathrm{ha}$. The similar result was also reported by Prabhakar and Saref (1991), Pyare and Dwivedi (2005), Sarawagi et al., (1999).
Data presented in table 1 shows that the more plant population $\mathrm{m}^{2}$ at 30 days (20.52) was find out to $\mathrm{P}_{3}$ which was non significantly superior over $\mathrm{P}_{2}$ (20.32), $\mathrm{P}_{1}$ (20.12) and $\mathrm{P}_{0}$ (19.95) respectively. The height of plant is an important plant characters which has indicate an idea about its growth. The data recorded on shoot length $(\mathrm{cm}$.) in table 1 shows that the maximum plant height was recorded in $\mathrm{P}_{3}$ i.e. $7.94 \mathrm{~cm} .28 .07 \mathrm{~cm}$, and $47.56 \mathrm{~cm}$. at 30,60 , and 90 days after sowing. At 90 days the different phosphorus levels were significantly increase height of main shoot $(\mathrm{cm}$.) with increasing phosphorus levels up to $\mathrm{P}_{3}$. The data on number of branches per plant were presented table 1 shows that the maximum primary and secondary branches / plant were recorded to $\mathrm{P}_{3}$ phosphorus levels i.e. 5.51 and 6.77 which were significantly higher over $\mathrm{P}_{1}$ and $\mathrm{P}_{0}$. The $\mathrm{P}_{2}$ was also significantly superior over $\mathrm{P}_{1}$ and $\mathrm{P}_{0}$ regarding primary and secondary branches / plant. The $\mathrm{P}_{1}$ and $\mathrm{P}_{0}$ were statically at par in case of both types of branches in order to $\mathrm{P}_{3}, \mathrm{P}_{2}, \mathrm{P}_{1}$ and $\mathrm{P}_{0}$ in different branches per plant respectively. Number of nodules per plant data presented in table 1 the highest nodules/plant was counted in $\mathrm{P}_{3} 2.17,2.09$, and 2.56 at 30,60 and 90 days of crop which was significantly higher 90 days over $\mathrm{P}_{2}, \mathrm{P}_{1}$ and $\mathrm{P}_{0}$ respectively. The phosphorus level such as $\mathrm{P}_{2}$ and $\mathrm{P}_{1}$ were at par and three both were significantly more over $\mathrm{P}_{0}$ in this regards.

Fresh weight per plant (g.) data presented in table 2 showed that the maximum fresh weight/plant were recorded in $\mathrm{P}_{3}$, phosphorus levels i.e. $3.75 \mathrm{~g}, 13.28 \mathrm{~g}$ and $22.50 \mathrm{~g}$. At 30,60 and 90 days stage of crop. At final data i.e. 90 days it was significantly maximum over other levels of phosphorus were significantly differed among each other in this regards. The data on dry weight per plant (g.) has been presented in table 2 showed that the maximum dry weight / plant were recorded in $\mathrm{P}_{3}$, phosphorus i.e. $2.06 \mathrm{~g} .7 .30 \mathrm{~g}$. and $13.50 \mathrm{~g}$. at 
30, 60 and 90 days stage of crop. The $\mathrm{P}_{3}$ phosphorus levels was increased significantly maximum dry weight per plant (g.) over $\mathrm{P}_{2}, \mathrm{P}_{1}$ and $\mathrm{P}_{0}$ respectively at 90 days age of crop $\mathrm{P}_{2}$ and $\mathrm{P}_{1}$ levels of phosphorus were nonsignificant and these both levels were also significantly superior over $\mathrm{P}_{0}$ in this regard.

Yield attribute characters number of pods per plant, weight of pods/ plant (g), number of seed / plant, weight of seed per plant (g.) and test weight (g.). The data presented in table 3 show that number of pods/plant was significantly affected by different levels of phosphorus the significantly more value was recorded in $\mathrm{P}_{3}$ (34.41) phosphorus levels followed by $\mathrm{P}_{2}, \mathrm{P}_{1}$ levels of phosphorus and $\mathrm{P}_{0}$ respectively.

The weight of pods/plant (g.) was significantly influenced by different phosphorus levels expect $\mathrm{P}_{3}$ and $\mathrm{P}_{2}$ levels. The maximum value was recorded in $\mathrm{P}_{3}$ (22.31) followed by $\mathrm{P}_{2}$ (19.90), $\mathrm{P}_{1}$ (18.13), phosphorus levels and $\mathrm{P}_{0}$ (17.03) respectively.

Number of seeds /pods have been counted and presented table 3. significantly affected by different phosphorus levels significantly more value was recorded in $\mathrm{P}_{3}$ (60.76) followed by $\mathrm{P}_{2}$ (55.15), $\mathrm{P}_{1}$ (41.68), phosphorus levels and $\mathrm{P}_{0}$ (33.33) respectively.

Table.1 Effect of different treatment on initial plant population $/ \mathrm{m}^{2}$, height of main shoot $(\mathrm{cm}$.), no. of branches, no. of nodules per plant as influenced by different stage of treatments

\begin{tabular}{|c|c|c|c|c|c|c|c|c|c|c|}
\hline \multirow[t]{2}{*}{$\begin{array}{l}\text { Treat } \\
\text { ment }\end{array}$} & \multirow{2}{*}{$\begin{array}{l}\text { Phosphoru } \\
\text { s levels kg } \\
\left(\mathrm{P}_{2} \mathrm{O}_{5} / \mathrm{ha}\right)\end{array}$} & \multirow{2}{*}{$\begin{array}{l}\text { Initial } \\
\text { plant } \\
\text { popul } \\
\text { ation } \\
/ \mathrm{m}^{2}\end{array}$} & \multicolumn{3}{|c|}{ Plant height (cm.) } & \multirow{2}{*}{$\begin{array}{l}\text { Pri } \\
\text { mar } \\
\text { y- } \\
\text { bran } \\
\text { ches }\end{array}$} & \multirow{2}{*}{$\begin{array}{l}\text { Secon } \\
\text { dary } \\
- \\
\text { branc } \\
\text { hes }\end{array}$} & \multicolumn{3}{|c|}{$\begin{array}{l}\text { Number of nodules / } \\
\text { plant }\end{array}$} \\
\hline & & & $\begin{array}{l}30 \\
\text { Days }\end{array}$ & $\begin{array}{l}60 \\
\text { Days }\end{array}$ & $\begin{array}{l}90 \\
\text { Days }\end{array}$ & & & $\begin{array}{l}30 \\
\text { Days }\end{array}$ & $\begin{array}{l}60 \\
\text { Days }\end{array}$ & $\begin{array}{l}90 \\
\text { Days }\end{array}$ \\
\hline $\mathbf{P}_{0}$ & 0 Control & 19.95 & 7.00 & 25.28 & 39.63 & 4.88 & 5.62 & 1.52 & 1.45 & 1.89 \\
\hline $\mathbf{P}_{1}$ & $25 \mathrm{~kg}$ & 20.12 & 7.43 & 26.83 & 43.12 & 5.15 & 5.92 & 1.95 & 1.68 & 2.25 \\
\hline $\mathbf{P}_{2}$ & $40 \mathrm{~kg}$ & 20.32 & 7.65 & 27.37 & 44.91 & 5.32 & 6.49 & 2.08 & 1.79 & 2.31 \\
\hline $\mathbf{P}_{3}$ & $55 \mathrm{~kg}$ & 20.52 & 7.94 & 28.07 & 47.56 & 5.51 & 6.77 & 2.17 & 2.09 & 2.56 \\
\hline \multicolumn{2}{|l|}{ S.E. \pm} & 0.85 & 0.12 & 0.48 & 0.66 & 0.16 & 0.21 & 0.13 & 0.05 & 0.05 \\
\hline \multicolumn{2}{|c|}{ C.D. at $5 \%$} & N.S & 0.25 & 0.98 & 1.35 & 0.33 & 0.43 & 0.27 & 0.09 & 0.11 \\
\hline
\end{tabular}

Table.2 Effect of fresh weight and dry weight per plant $(\mathrm{g})$ influenced by different treatments

\begin{tabular}{|c|c|c|c|c|c|c|c|}
\hline \multirow[t]{2}{*}{ Treatment } & \multirow{2}{*}{$\begin{array}{l}\text { Phosphoru } \\
\text { s levels kg } \\
\left(\mathrm{P}_{2} \mathrm{O}_{5} / \mathrm{ha}\right)\end{array}$} & \multicolumn{3}{|c|}{ Fresh weight / plant (g.) } & \multicolumn{3}{|c|}{ Dry weight / plant (g.) } \\
\hline & & 30 Days & 60 Days & 90 Days & 30 Days & 60 Days & 90 Days \\
\hline $\mathbf{P}_{0}$ & $\begin{array}{ll}0 & \mathrm{~kg} \\
\text { Control }\end{array}$ & 3.31 & 11.96 & 18.57 & 1.82 & 6.58 & 11.25 \\
\hline $\mathbf{P}_{1}$ & $25 \mathrm{~kg}$ & 3.51 & 12.69 & 20.40 & 1.93 & 6.98 & 12.24 \\
\hline$\overline{\mathbf{P}_{2}}$ & $40 \mathrm{~kg}$ & 3.62 & 12.96 & 21.25 & 1.99 & 7.12 & 12.75 \\
\hline $\mathbf{P _ { 3 }}$ & $55 \mathrm{~kg}$ & 3.75 & 13.28 & 22.50 & 2.06 & 7.30 & 13.50 \\
\hline \multicolumn{2}{|l|}{ S.E. \pm} & 0.11 & 0.36 & 0.54 & 0.05 & 0.22 & 0.31 \\
\hline \multicolumn{2}{|l|}{ C.D. at $5 \%$} & 0.23 & 0.73 & 1.11 & 0.11 & 0.45 & 0.65 \\
\hline
\end{tabular}


Table.3 Effect of No of pods /plant, weight of pods/plant (g), Weight of seeds/plant (g), weight of 1000 seeds $(\mathrm{g})$ influenced by different treatments

\begin{tabular}{|c|c|c|c|c|c|c|}
\hline Treatment & $\begin{array}{l}\text { Phosphorus } \\
\text { levels kg } \\
\left(\mathrm{P}_{2} \mathrm{O}_{5} / \mathrm{ha}\right)\end{array}$ & $\begin{array}{ll}\text { No of } \\
\text { pods } \\
\text { /plant }\end{array}$ & $\begin{array}{l}\text { weight of } \\
\text { pods } \\
\text { /plant (g) }\end{array}$ & $\begin{array}{ll}\text { No of } & \text { of } \\
\text { seeds } & \\
\text { /plant } & \end{array}$ & $\begin{array}{l}\text { Weight of } \\
\text { seeds } \\
\text { /plant (g) }\end{array}$ & $\begin{array}{l}\text { Weight of } \\
100 \text { seeds } \\
(\mathrm{g})\end{array}$ \\
\hline $\mathbf{P}_{0}$ & $0 \mathrm{~kg}$ Control & 29.25 & 17.03 & 33.33 & 12.30 & 248.83 \\
\hline $\mathbf{P}_{1}$ & $25 \mathrm{~kg}$ & 30.96 & 18.13 & 41.68 & 13.46 & 252.25 \\
\hline $\mathbf{P}_{2}$ & $40 \mathrm{~kg}$ & 32.97 & 19.90 & 55.15 & 13.66 & 253.91 \\
\hline $\mathbf{P}_{3}$ & $55 \mathrm{~kg}$ & 34.41 & 22.31 & 60.76 & 16.53 & 262.33 \\
\hline \multicolumn{2}{|l|}{ S.E. \pm} & 0.58 & 0.38 & 0.95 & 0.25 & 4.69 \\
\hline \multicolumn{2}{|l|}{ C.D. at $5 \%$} & 1.18 & 1.19 & 1.95 & 0.52 & 9.58 \\
\hline
\end{tabular}

Table.4 Yield influenced by different treatments

\begin{tabular}{|c|c|c|c|c|c|}
\hline \multirow[t]{2}{*}{ Treatment } & \multirow{2}{*}{$\begin{array}{ll}\text { Phosphorus } & \text { levels } \\
\mathrm{kg}\left(\mathrm{P}_{2} \mathrm{O}_{5} / \mathrm{ha}\right) & \end{array}$} & \multirow{2}{*}{$\begin{array}{l}\text { Biomass } \\
\text { yield (q/ha) }\end{array}$} & \multicolumn{3}{|c|}{ Yield characters } \\
\hline & & & $\begin{array}{l}\text { Seed yield } \\
\text { (q/ha) }\end{array}$ & $\begin{array}{l}\text { Straw yield } \\
\text { (q/ha) }\end{array}$ & $\begin{array}{l}\text { Harvest } \\
\text { Index }(\%)\end{array}$ \\
\hline$P_{0}$ & 0 Control & 23.08 & 11.45 & 11.63 & 49.60 \\
\hline $\mathbf{P}_{1}$ & $25 \mathrm{~kg}$ & 25.19 & 12.50 & 12.63 & 49.65 \\
\hline $\mathbf{P}_{2}$ & $40 \mathrm{~kg}$ & 29.80 & 14.77 & 15.03 & 49.62 \\
\hline $\mathbf{P}_{3}$ & $55 \mathrm{~kg}$ & 34.36 & 17.00 & 17.36 & 49.46 \\
\hline \multicolumn{2}{|l|}{ S.E. \pm} & 0.52 & 0.31 & 0.29 & 0.09 \\
\hline \multicolumn{2}{|l|}{ C.D. at 5\% } & 1.06 & 0.63 & 0.60 & NS \\
\hline
\end{tabular}

The data weight of seeds /plants (g.) have been recorded and presented table 3 that maximum weight of seeds/plant (g.) was recorded in $\mathrm{P}_{3}$ (16.53) phosphorus levels which was at par with $\mathrm{P}_{2}$ (13.66) and significant over $\mathrm{P}_{1}$ (13.46) phosphorus levels and $\mathrm{P}_{0}(12.30)$ respectively.

Table 3 shows increasing levels of phosphorus was also increased weight of 100 seeds (g). The $\mathrm{P}_{3}$ (262.33) levels of phosphorus was at par with $\mathrm{P}_{2}(252.91)$ and these both levels were significant over $\mathrm{P}_{1}$ (252.25) and $\mathrm{P}_{0}(248.83)$ respectively. The $\mathrm{P}_{1}$ and $\mathrm{P}_{0}$ were also non-significant in this regards.

Biomass yield ( $\mathrm{q} / \mathrm{ha}$ ), seed yield ( $\mathrm{q} / \mathrm{ha})$, straw yield (q/ha) and harvest index (\%) are recorded from the net plot area basis and presented in table 4. The significantly maximum value was recorded in $\mathrm{P}_{3}$ (34.36) phosphorus levels followed by $\mathrm{P}_{2}$ (29.80), $\mathrm{P}_{1}$ (25.19) and $\mathrm{P}_{0}$ (23.08) phosphorus levels regards.

Seed yield (q/ha) are recorded and presented in table 4. The significantly increased with increasing levels of phosphorus up to $\mathrm{P}_{3}$ (17.00) levels. The value in order to $P_{3}$ (17.00), $\mathrm{P}_{2}$ (14.77), $\mathrm{P}_{1}$ (12.50) and $\mathrm{P}_{0}$ (11.45) phosphorus levels respectively.

Straw yield ( $\mathrm{q} / \mathrm{ha}$ ) have been recorded and presented in table 4 and significantly affected under varying levels of phosphorus. The phosphorus levels $\mathrm{P}_{3}$ (17.36) produced significantly maximum straw yield (q/ha) over $\mathrm{P}_{2}$ (15.03), and $\mathrm{P}_{1}$ (12.63) phosphorus levels and $\mathrm{P}_{0}$ (11.63) respectively. Harvest 
index 49.76 was no significantly affected by different levels of phosphorus.

The height of main shoots $47.56 \mathrm{~cm}$, fresh weight /plant $22.50 \mathrm{~g}$ and dry weight/plant $13.50 \mathrm{~g}$ were recorded significantly maximum in $\mathrm{P}_{3}$ (55kg $\mathrm{P}_{2} \mathrm{O}_{5} /$ ha application) over $\mathrm{P}_{2}$ (40 $\mathrm{kg}), \mathrm{P}_{1}(25 \mathrm{Kg}), \mathrm{P}_{0}$ (control), respectively. The primary 5.51 and secondary 6.77 branches/plant were recorded significantly more in $\mathrm{P}_{3}$ over $\mathrm{P}_{1}$ and $\mathrm{P}_{0}$ respectively. However, the number of nodules/ plant 2.56 was recorded for $\mathrm{P}_{2}$ which is higher than other levels of phosphorus. The yield of contributing characters such as number of pods/plant 34.41, weight of pods/plant $22.31 \mathrm{~g}$ number of seeds/plant 60.76, weight of seeds/plant $16.53 \mathrm{~g}$, weight of 100 seeds $262.33 \mathrm{~g}$ was recorded significantly maximum in $\mathrm{P}_{3} 55 \mathrm{~kg} \mathrm{P}_{2} \mathrm{O}_{5} /$ ha application over $\mathrm{P}_{1} 25 \mathrm{~kg}$ $\mathrm{P}_{2} \mathrm{O}_{5} /$ ha and $\mathrm{P}_{0}$ respectively. The biomass yield $34.36 \mathrm{q} / \mathrm{ha}$ and straw yield $17.36 \mathrm{q} / \mathrm{ha}$ were recorded significantly maximum in $\mathrm{P}_{3}$ followed by $\mathrm{P}_{2}, \quad \mathrm{P}_{1}$ and $\mathrm{P}_{0}$ (control) respectively. Harvest index 49.76 was no significantly affected by different levels of phosphorus.

\section{Acknowledgement}

The authors are grateful to ICAR New Delhi, Niche Area of Excellence Programme- Farm
Mechanization in Rainfed Agriculture, for granting financial assistant during the course of the investigation.

\section{References}

Anonymous, 2012-13. Icar-dare-annualreports/2012-13/content-12-13.

Aziz, M.A. 2000. The response of chickpea to nipping Pakistan Journal of Scientific and Industrial Research 43 (93): 191192.

Jackson, M.L. 1973. Soil Chemical Analysis. Prentice Hall of India Pvt. Ltd., New Delhi, 498

Prabhakar, M. and Saraf C.S. 1991. Influence irrigation and phosphorus on growth, yield and water use efficiency of chickpea (Cicer aritinum) genotypes. Indian J. Agron. 36 (3): 357-362.

Pyare, R. and Dwivedi, D.P. 2005. Yield economics and quality of Chickpea (Cicer aritinum) as affected by row spacing and phosphorus levels under limited Irrigation. Journal of crop Res. 29 (1): 95-100.

Sawires, E.S. 2001. Effect of phosphorus fertilization and micro nutrients on yield and yield components of Chickpea (Cicer aritinum). Annals of Agricultural Science Cairo 46 (1): 155-164.

\section{How to cite this article:}

Mukesh Kumar Pandey, Aditya Sirmour and Varun Pratap Jadaun. 2018. Study on the Effects of Phosphorus Levels on Growth and Yield of Chickpea (Cicer aritinum L.). Int.J.Curr.Microbiol.App.Sci. 7(01): 664-669. doi: https://doi.org/10.20546/ijcmas.2018.701.081 